\title{
Lymphotoxin $\beta$ receptor-mediated NFkB signaling promotes glial lineage differentiation and inhibits neuronal lineage differentiation in mouse brain neural stem/progenitor cells
}

Xiao Xiao ${ }^{1,2}$, Raj Putatunda ${ }^{2}$, Yonggang Zhang ${ }^{2}$, Priya V. Soni², Fang Li ${ }^{2}$ Ting Zhang ${ }^{2}$, Mingyang Xin², Jin Jun Luo ${ }^{3}$, John R. Bethea ${ }^{4}$, Yuan Cheng ${ }^{1 *}$ and Wenhui $\mathrm{Hu}^{2 *}$ (I)

\begin{abstract}
Background: Lymphotoxin ( $L T)$ is a lymphokine mainly expressed in lymphocytes. LTa binds one or two membraneassociated $L T \beta$ to form $L T a_{2} \beta_{1}$ or $L T a_{1} \beta_{2}$ heterotrimers. The predominant $L T a_{1} \beta_{2}$ binds to $L T \beta$ receptor (LTRR) primarily expressed in epithelial and stromal cells. Most studies on LT $R$ R signaling have focused on the organization, development, and maintenance of lymphoid tissues. However, the roles of LT $\beta R$ signaling in the nervous system, particularly in neurogenesis, remain unknown. Here, we investigated the role of LTßR-mediated NFKB signaling in regulating neural lineage differentiation.

Methods: The C57BL/6J wild-type and GFAP-dnlkBa transgenic mice were used. Serum-free embryoid bodies were cultured from mouse embryonic stem cells and further induced into neural stem/progenitor cells (NSCs/NPCs). Primary neurospheres were cultured from embryonic and adult mouse brains followed by monolayer culture for amplification/ passage. NFkB activation was determined by adenovirus-mediated NFkB-firefly-luciferase reporter assay and p65/RelB/p52 nuclear translocation assay. LTßR mRNA expression was evaluated by quantitative RT-PCR and LTRR protein expression was determined by immunohistochemistry and Western blot analysis. Multilabeled immunocytochemistry or immunohistochemistry followed by fluorescent confocal microscopy and quantitative analysis of neural lineage differentiation were performed. Graphing and statistical analysis were performed with GraphPad Prism software.

Results: In cultured NSCS/NPCs, $L T a_{1} \beta_{2}$ stimulation induced an activation of classical and non-classical NFkB signaling. The expression of LTßR-like immunoreactivity in GFAP ${ }^{+} / S O X 2^{+}$NSCs was identified in well-established neurogenic zones of adult mouse brain. Quantitative RT-PCR and Western blot analysis validated the expression of LTRR in cultured NSCS/NPCS and brain neurogenic regions. LTRR expression was significantly increased during neural induction. LTa $\mathrm{B}_{2}$ stimulation in cultured NSCS/ NPCs promoted astroglial and oligodendrocytic lineage differentiation, but inhibited neuronal lineage differentiation. Astroglial NFKB inactivation in GFAP-dnlkBa transgenic mice rescued LTßR-mediated abnormal phenotypes of cultured NSCS/NPCs. (Continued on next page)
\end{abstract}

\footnotetext{
* Correspondence: chengyuan023@aliyun.com; whu@temple.edu

'Department of Neurosurgery, The Second Affiliated Hospital of Chongqing Medical University, Chongqing 400010, China

${ }^{2}$ Center for Metabolic Disease Research, Department of Pathology and

Laboratory Medicine, Temple University Lewis Katz School of Medicine, 3500

N Broad Street, Philadelphia, PA 19140, USA

Full list of author information is available at the end of the article
} 
(Continued from previous page)

Conclusion: This study provides the first evidence for the expression and function of LTßR signaling in NSCS/NPCs. Activation of LTßR signaling promotes glial lineage differentiation. Our results suggest that neurogenesis is regulated by the adaptive immunity and inflammatory responses.

Keywords: Lymphotoxin, Neural stem cells, NFkB, Neural differentiation, Transgenic mice

\section{Background}

Neurogenesis involves the proliferation, migration, and lineage differentiation of neural stem/progenitor cells (NSCs/NPCs) during development and adult life. Defects or impairments in embryonic and adult neurogenesis have been implicated in a large array of neurodevelopmental disorders [1-6] and neurodegenerative diseases [7-10]. Optimizing adult neurogenesis to achieve functional recovery in patients with various types of nervous system injuries and diseases remains a daunting challenge. NSCs are characterized by their self-renewal and multipotent differentiation into various neural cell lineages, which depend upon the orchestral interplay between the intrinsic cellular properties and extrinsic environmental factors including immunity-related cytokines and chemokines $[11,12]$. Neuroinflammatory responses exhibit a double-edged sword role in neurogenesis $[13,14]$ and neurodegeneration $[15,16]$.

The nuclear factor $\kappa \mathrm{B}(\mathrm{NF} \kappa \mathrm{B})$ is well known for its critical role in inflammation, immunity, cancer, and neural plasticity. In most cell types, $\mathrm{NFK} B$ maintains cellular growth (proliferation) and survival. However, little is known about the role of $\mathrm{NFKB}_{\mathrm{K}}$ signaling in regulating neural differentiation of NSCs. Activation of NFKB by Toll-like receptor 2 (TLR2) induces neuronal differentiation whereas TLR4 activation inhibits neuronal differentiation of NSCs [17]. In p50 knockout mice, adult hippocampal NSCs exhibit 50\% reduction in neuronal differentiation while their proliferative capability does not change [18]. Our previous study showed that selective inhibition of the classical $\mathrm{NFKB}$ signaling retains the tripotent ability of differentiation and promotes self-renewal capability of NSCs, suggesting a role of NFKB signaling in mediating the differentiation of NSCs into NPCs at the very early stage [19].

Inflammatory mediators such as cytokines and chemokines have been shown to regulate neurogenesis [20-23]. Tumor necrosis factor (TNF) $\alpha$ has been extensively studied but its role in modulating neurogenesis remains controversial. The enhancing effect of TNFo on neuronal differentiation was first identified in rat NSCs [24]. TNF $\alpha$ promotes neurosphere aggregation in vitro [25]. TNF receptor 2(TNFR2)-derived peptide promotes neuronal lineage differentiation of NSCs [26]. However, TNF $\alpha$ treatment has no effect on neuronal differentiation and neurite outgrowth of murine adult NSCs $[27,28]$ and mouse embryonic stem cell-derived NPCs [29]. Several studies have demonstrated that TNF $\alpha$ promotes glial, rather than neuronal, lineage differentiation in NSCs [29-32]. Increasing evidence shows that some cytokines, such as IL-1 $\beta$ and IL- 6 , inhibit neuronal differentiation but promote glial lineage differentiation both in vitro and in vivo [29, 32-42] while others in contrast, such as interferon- $\gamma$, inhibit the proliferation but promote neuronal differentiation of NSCs $[28,29,32,43$, 44]. Noteworthy, different outcomes induced by these factors reflect a different intricate mechanism in regulation of neurogenesis and imply that other inflammatory mediators may also share similar intracellular signal pathways to regulate neurogenesis.

Lymphotoxin (LT) is a lymphokine mainly expressed in T and B lymphocytes. LT $\alpha$ (also known as TNF $\beta$ ) is devoid of a transmembrane domain and self-associates to form homotrimers $\mathrm{LT}_{3}$ that binds to TNFR [45]. LT $\alpha$ also binds to one or two membrane-associated LT $\beta$ to form $\mathrm{LT}_{2} \beta_{1}$ and $\mathrm{LTo} \beta_{1} \beta_{2}$ heterotrimers, respectively [46, 47]. The predominant heterotrimer $\mathrm{LT} \alpha_{1} \beta_{2}$ binds to $\mathrm{LT} \beta$ receptor (LT $\beta R$ ) primarily expressed on epithelial and stromal cells [48] and cells of the myeloid lineage [49]. Most studies on LT $\beta R$ signaling have focused on the organization, development, and maintenance of lymphoid tissues [48] and their role in adaptive and innate immune responses [50]. LT/R signaling modulates follicular dendritic cell maintenance and germinal center formation in lymph nodes [51]. Soluble LTßR-immunoglobulin fusion protein treatment disrupts follicles, marginal zone and germinal center in spleen [52]. LT $\beta R$ signaling contributes to the formation of tertiary lymph organ, the unique immune cell aggregates at the sites of persistent inflammation [53-55].

However, the roles of LT $\beta R$ signaling in the nervous system, particularly during neurogenesis, have not yet been investigated. The aims of this study were to determine whether LT $\beta R$ is expressed in NSCs/NPCs both in vitro and in vivo and to identify the role of LT $\beta R$-mediated classical and non-classical NFKB pathways in regulating neural lineage differentiation of NSCs/NPCs.

\section{Methods}

\section{Reagents and antibodies}

TNF $\alpha, L T \alpha_{1} \beta_{2}$, IL-1 $\beta$, B-cell activating factor (BAFF), CD40L, and LIGHT were obtained from PeproTech. APQ [NF- $\mathrm{kB}$ activation inhibitor, 6-amino-4-(4-phenoxyphenylethylamino)quinazoline] was from EMD Chemicals and 
dissolved in DMSO. Antibodies against LTßR(M-110), Calretinin(N-18), Doublecortin (DCX, C-18), Myelin basic protein (MBP, D-18), Sox2(Y-17), p65(C-20), GAPDH and Lamin A/C(636) were obtained from Santa Cruz Biotechnology. RelB and p100/p52 were from Cell Signal Technology. Mouse anti-NeuN antibody was from Millipore. Chicken anti-glial fibrillary acidic protein (GFAP), anti-Neuronspecific class III $\beta$-tubulin (Tuj1), and anti-Nestin antibodies were from Aves. Rabbit anti-GFAP (Z0334) was from Dako. All other reagents were from Sigma.

\section{Animals and brain specimen collection}

All procedures for animal usage were complied with the guidelines of the National Institutes of Health and approved by the Institutional Animal Care and Use Committee (IACUC) at Temple University. The transgenic (TG) mice carrying the $\mathrm{NF}_{k} \mathrm{~B}$ super-inhibitor dominant-negative $\mathrm{I} \kappa \mathrm{B} \alpha(\mathrm{dnI} \kappa \mathrm{B} \alpha)$ transgene driven by the promoter of Glial fibrillary acidic protein (GFAP) were obtained from Dr. Bethea's Lab at the University of Miami and maintained by breeding heterozygous GFAP$\mathrm{dnI} \mathrm{BB} \alpha$ males with wild-type (WT) females [56]. WT littermates were used as controls. After euthanization, the brains were collected and different regions of interest were dissected for further studies. Samples for RNA and protein extractions were snap-frozen in liquid nitrogen and stored at $-80^{\circ} \mathrm{C}$.

\section{Neurosphere and monolayer cultures of NSCs/NPCs}

Primary neurospheres were cultured from the subventricular zone (SVZ) of adult mice $(2-3$ months old, $n=3)$ as described previously $[19,57]$. Briefly, whole brains were cut into 0.5 -mm-thick coronal slices using mouse stainless steel brain matrices. The SVZ tissues were dissected out carefully and cut into small pieces, digested with Accutase (Sigma, St. Louis, MO) for 25-30 min, and triturated. The dissociated cells were cultured at a density of $2 \times$ $10^{5}$ cells/ml in DMEM/F12 NSC/NPC proliferation medium containing $\times 1$ B27 Supplement, $20 \mathrm{ng} / \mathrm{ml}$ epidermal growth factor (EGF), $10 \mathrm{ng} / \mathrm{ml}$ basic fibroblast growth factor (bFGF), and 0.2\% Heparin (StemCell Technologies). Medium was changed every other day, and primary neurospheres were formed within 37 days.

For expansion, the adherent monolayer culture was performed by dissociating the primary neurospheres with Accutase and seeding in plates coated with matrigel. Half volume of the proliferation medium was changed every other day. Neural lineage differentiation of the monolayer culture was initiated by replacing the proliferation media with the differentiation media containing DMEM/F12, $\times 1$ B27 and $\times 1$ N2 Supplement without EGF/bFGF.
Neural induction of mouse embryonic stem cells (ESCs) Mouse ESCs from Transgenic Core Facility at Temple University were cultured in ESC media containing Advanced DMEM (Gibco 12,491), 10\% fetal bovine serum (FBS), $\times 1$ Penicillin/Streptomycin/Glutamine (Invitrogen), and $0.1 \mathrm{mM}$ 2-Mercaptoethanol. After initial culture on $60-\mathrm{mm}$ dish for $2-4 \mathrm{~h}$ to allow the attachment of mouse embryonic fibroblast, the suspension media containing ESCs were transferred to tissue culture 6-well plate, and cultured at $37{ }^{\circ} \mathrm{C}, 5 \% \mathrm{CO} 2$ with daily media change until ESC colonies were formed. Serum-free EB was generated following previously described protocol [58]. Briefly, ESC colonies were harvested without dissociation and re-plated on suspension 6-well plate for 1-3 days to generate EB. Then, the EBs were re-plated in neural induction medium containing equal volume of DMEM/ F12 with N2 supplement $(\times 1)$ and Neurobasal Medium with B27 supplement $(\times 1)$, plus $\times 1$ Penicillin/Streptomycin/Glutamine. After 7 days, serum-free, floating EB had developed. Further culture for 7-14 days in NSC/ NPC proliferation medium as described above generated NSCs/NPCs.

\section{Adenovirus-mediated NFKB-firefly-luciferase reporter assay}

NSCs/NPCs were cultured in a 96-well plate and infected with adenovirus carrying the $\mathrm{NF}_{\kappa} \mathrm{B}$-firefly-luciferase reporter (Vector Biolabs) at a multiplicity of infection of 10 for $24 \mathrm{~h}$. The cells in 6 wells per group were treated with or without indicated cytokines for $24 \mathrm{~h}$, including TNF $\alpha$ (10 ng/ml), IL1 $\beta$ (10 ng/ml), LT $\alpha_{1} \beta_{2}(100 \mathrm{ng} / \mathrm{ml})$, BAFF (100 ng/ml), CD40L (100 ng/ml), and LIGHT (100 ng/ml). The cell lysate was prepared for measuring of firefly-luciferase activity using the ONE-Glo luciferase assay system (Promega). Luminescence was quantified in a 2104 EnVision $^{\circledR}$ Multilabel Reader (PerkinElmer).

\section{Quantitative reverse transcription-polymerase chain reaction (RT-qPCR)}

Cultured ESCs, EBs, NSCs/NPCs, or snap-frozen brain tissues were processed with an RNeasy Mini kit (Qiagen) according to the manufacturer's instruction for total RNA extraction. RNase-Free DNase Set (Qiagen) was used to remove any potentially residual genomic DNA through oncolumn DNase digestion. High Capacity cDNA Reverse Transcription Kit (Invitrogen, Grand Island, NY) was used for cDNA synthesis from $2 \mu \mathrm{g}$ of RNA for each sample using random hexanucleotide primer. Quantitative PCR (qPCR) was performed in a BioRad CFX qPCR instrument using an $\mathrm{SYBR}^{\oplus}$ Green PCR Master Mix Kit (BioRad). One pair of mouse LT $\beta R$ primers targeted the range 786-923 nucleotide (5' -gcagctccaggtacctcctactcg- 3 ' on exon- 6 and 5 '-cctcatccaggcacaggccaggac-3' on exon-7) of mouse LT $\beta R$ 
(NM_020736.3). The primers for mouse housekeeping gene Ppia were forward $5^{\prime}$-gcccagtatgcttgggtatc- $3^{\prime}$ and reverse $5^{\prime}$-tgctgactcccagaacaga- $3^{\prime}$, or $\beta$-actin were forward $5^{\prime}$-aagagctatgagctgcctga- $3^{\prime}$ and reverse $5^{\prime}$-tacggatgtcaacgtcacac-3'. Each sample was tested in triplicate. Cycle threshold $(\mathrm{Ct})$ values were obtained graphically for LT $\beta R$ and Ppa2 or $\beta$-actin. Their difference $(\Delta \mathrm{Ct})$ was used to obtain $\Delta \Delta \mathrm{Ct}$ values by subtracting the $\Delta \mathrm{Ct}$ values of control samples from those of experimental samples. Relative fold change in gene expression was calculated as $2-\Delta \Delta \mathrm{Ct}$.

\section{Western blot analysis}

Culture NSCs/NPCs or snap-frozen brain tissues were lysed at $4{ }^{\circ} \mathrm{C}$ for $30 \mathrm{~min}$ in Triton X-100-based lysis buffer (20 mM Tris- $\mathrm{HCl}$ (pH 7.4), 1\% Triton X-100, 5 mM ethylenediaminetetraacetic acid, $5 \mathrm{mM}$ dithiothreitol, $150 \mathrm{mM}$ $\mathrm{NaCl}, 1 \mathrm{mM}$ phenylmethylsulfonyl fluoride, $\times 1$ proteinase inhibitor cocktail (Cayman Chemical, Ann Arbor, MI), $1 \mathrm{mM}$ sodium orthovanadate and $30 \mathrm{mM} \mathrm{NaF}$ ). After centrifugation at $20,000 \mathrm{~g}$ for $20 \mathrm{~min}$ at $4{ }^{\circ} \mathrm{C}$, the supernatant was collected for protein concentration determination with a Pierce BCA Protein Assay Kit (cat\# 23225). An equal amount of protein lysate $(20 \mu \mathrm{g})$ was resolved by the SDS-polyacrylamide gel electrophoresis system and transferred to nitrocellulose membrane (BioRad). The SeeBlue prestained protein standards (Invitrogen) were used as a molecular weight reference. The Odyssey CLx Infrared Fluorescent Western Blot system (LI-COR, Lincoln, NE) was used according to the manufacture's instruction. Briefly, after blocking with Odyssey blocking buffer containing $0.1 \%(v / v)$ Tween 20 , the membranes were incubated overnight at $4{ }^{\circ} \mathrm{C}$ with goat anti-LT $\beta R$ polyclonal antibody (1:500, SC-8376, Santa Cruz) and mouse anti-GAPDH monoclonal antibody (1:1000, Sigma). After washing three times, the membrane was incubated with fluorescently conjugated secondary antibodies (IRDye 680LT-conjugated anti-mouse or IRDye $800 \mathrm{CW}$ conjugated anti-rabbit) for $1 \mathrm{~h}$ at room temperature. The membranes were scanned and analyzed using the Odyssey Infrared Imaging System. Relative signal intensities were determined using the LI-COR imaging software, which is independent of the image intensity adjustment.

Immunocytochemical staining of cultured NSCs/NPCs and immunohistochemical staining of mouse brain tissues

Cultured NSCs/NPCs upon differentiation in 16-well chambered slides were fixed for $20 \mathrm{~min}$ in $2 \%$ paraformaldehyde and 25\% sucrose in PBS. After three rinses, the cells were treated with $0.5 \%$ Triton X-100 PBS for $20 \mathrm{~min}$ and blocked by $10 \%$ donkey serum or $2 \%$ bovine serum albumin/PBS for $2 \mathrm{~h}$. Cells were incubated overnight at $4{ }^{\circ} \mathrm{C}$ with indicated primary antibodies. After washing three times, cells were incubated with corresponding secondary antibodies for $1 \mathrm{~h}$ and with DAPI for $5 \mathrm{~min}$. After three rinses with PBS, the cells were mounted with a coverslip using antifading aqueous mounting media (Biomeda, Foster City, CA) and analyzed under fluorescence microscope and confocal imaging analysis.

For multilabeled immunohistochemistry, mice were euthanized with an overdose of pentobarbital solution and transcardially perfused with $4 \%$ paraformaldehyde. The brains were dissected, postfixed overnight in the same fixative, and cryopreserved with buffered $30 \%$ sucrose. A series of coronal sections of brain at $40 \mu \mathrm{m}$ thickness were cut on a freezing sliding microtome and collected in a serial manner and stored at $-20^{\circ} \mathrm{C}$. Then, standard multiple-labeled immunofluorescent staining was performed. Briefly, sections were permeated for $30 \mathrm{~min}$ in PBS containing $0.5 \%$ Triton X-100 and blocked with $10 \%$ normal donkey serum for $30 \mathrm{~min}$. The sections were incubated with indicated primary antibodies in PBS with $0.1 \%$ Triton X-100 overnight at $4{ }^{\circ} \mathrm{C}$. After washing three times each for $10 \mathrm{~min}$, the sections were incubated with corresponding Alexa Fluor ${ }^{\circledR}$ conjugated donkey secondary antibody (1:400; Invitrogen, Grand Island, NY) for $1 \mathrm{~h}$ at room temperature. DAPI was used for nuclear counterstaining. After three rinses with PBS, sections were mounted on a slide and coverslipped with antifading aqueous mounting media (Biomeda, Foster City, CA).

For confocal imaging analysis, samples were viewed on a Leica SP8 confocal microscope system. Differential visualization of three or four fluorophores Alexa-488, Alexa-594, Alexa-680 and DAPI was obtained via specific filter combinations. Samples were scanned sequentially to avoid any potential for fluorophore bleedthrough. The Z-stack scanning images $(1024 \times 1024$ pixels) through 0.5 or $1.0 \mu \mathrm{m}$ optical sections were obtained under identical exposure conditions and processed through the build-in processing tools. For quantification analysis, at least 8 images were collected for each condition and the Z-stack images for equal number of Z-stacks were maximized for further identification and manual counting of indicated positive cells. The percentage of indicated positive cells over total DAPI-positive nucleus was calculated.

\section{Statistical analysis}

All statistical analysis was performed using Prism GraphPad 6.0. Significance was determined between multiple genotypes using a one-way ANOVA with Tukey post-hoc analysis. An unpaired two-tailed Student's $t$ test was performed between two groups of different treatments. The $p$ value at $<0.05$ and $<0.01$ were used for statistical significance. 


\section{Result}

Lymphotoxin $\alpha_{1} \beta_{2}\left(L T a_{1} \beta_{2}\right)$ activates classical and nonclassical NFKB signaling pathways in neural stem/progenitor cells

In our previous study, we found that $\mathrm{LT} \alpha_{1} \beta_{2}$ stimulates activation of NFkB-luciferase reporter in mouse embryonic/neonatal SVZ NSCs/NPCs and enteric neuronal cell line [19], indicating the immunological impact on the neurogenesis in the developmental period [59]. To corroborate this observation in adult neurogenesis, we repeated similar NFkB-luciferase reporter assay in SVZ NSCs/NPCs from adult mice (2-3 months old). We examined various stimulators for classical and nonclassical NFKB signaling pathways $[19,60]$. Although the three selected cytokines TNF $\alpha$ and IL-1 $\beta$ (the bestknown activators for the classical $N_{k} B$ pathways) as well as $L T \alpha_{1} \beta_{2}$ (for both pathway) [61-66] induced significant activation of NFkB-luciferase reporter in adult SVZ NSCs/NPCs, the induction pattern in adult NSCs/ NPCs exhibited slight difference from embryonic NSCs/ NPCs [19], with lower induction by $\mathrm{LT}_{1} \beta_{2}$ v.s. TNF $\alpha$ in adult SVZ NSCs/NPCs (Fig. 1a). Interestingly, similar induction patterns occurred in both male and female littermate mice (Fig. 1a); thus, both genders were used randomly in the following studies. The $L T \alpha_{1} \beta_{2}$-induced $\mathrm{NF}_{k} \mathrm{~B}$ activation was dose-dependent with a narrow window
(Fig. 1b). However, the selected cytokines BAFF and CD40L (well-known activators for the non-classical pathway) and LIGHT (for both pathway) [67-69] had no effects on NFkB-luciferase reporter activity in cultured adult SVZ NSCs/NPCs (Fig. 1a), consistent with our previous observation on BAFF in embryonic SVZ NSCs/NPCs [19]. The response to BAFF signaling was confirmed by Western blotting showing the nuclear translocation of RelB, a main marker for non-classical pathway (Fig. 1c). However, $\mathrm{LT} \alpha_{1} \beta_{2}$ treatment induced the nuclear translocation of RelB and p52 for non-classical and p65 for classical pathway in adult NSCs/NPCs (Fig. 1c, d), which is also consistent with our previous observation in mouse enteric neuronal cell line [19]. Taken together, administration of $\operatorname{LT} \alpha_{1} \beta_{2}$ induces activation of both classical and non-classical NFKB pathways in mouse SVZ NSCs/NPCs.

\section{LT $\beta R$ expression exists in neural stem cells both in vitro and in vivo}

Previous studies have shown that LT $\beta$ receptor (LT $\beta R$ ) is expressed primarily in epithelial and stromal cells [49, 70]. There are no conclusive reports about the expression of LT $\beta R$ in brain and neural cells. Our observation on the $\mathrm{LT}_{1} \beta_{2}$-induced activation of $\mathrm{NF} \mathrm{KB}$ signaling in NSCs/NPCs indicates the presence of its receptor LT $\beta R$ a
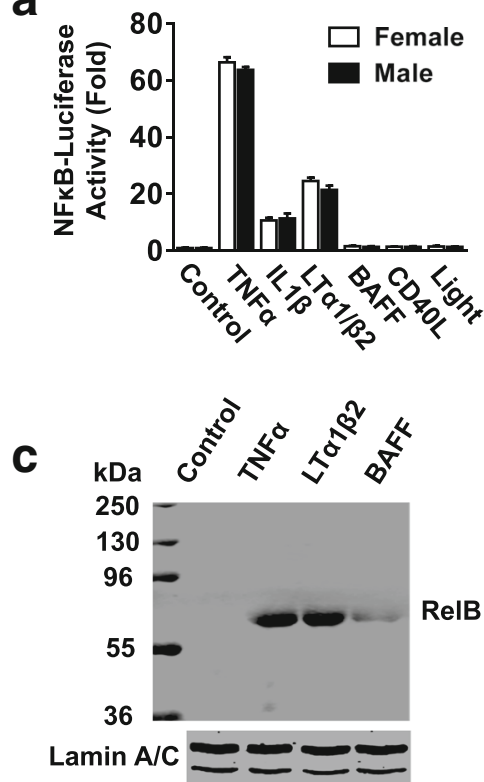

b

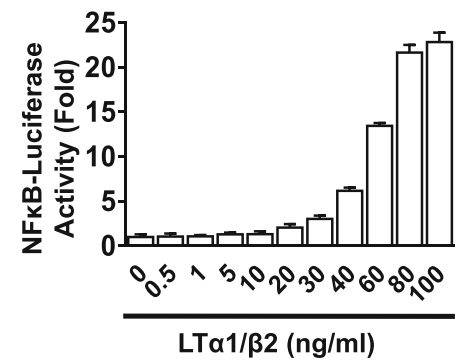

d

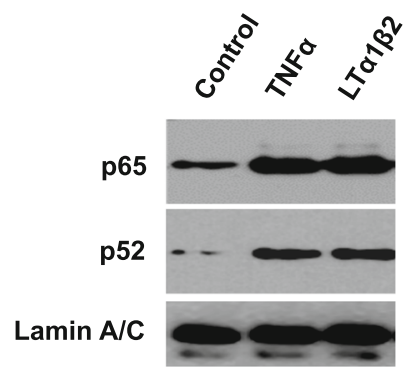

Fig. $1 \mathrm{Lta1} / \beta 2$ activates classical and non-classical NFKB signaling pathway in mouse neural stem/progenitor cells (NSCS/NPCS). a, b Adenovirus-mediated NFkB-firefly-luciferase reporter assay showing a comparison of classical and non-classical NFkB stimulators (a) and a dose response of Lta1/32 (b) in NSCS/NPCS. Dissociated NSCS/NPCs cultured from adult mouse brain subventricular zones (SVZ) were plated on 96-well plate and infected with adenovirus carrying NFKB firefly-luciferase at 50 multiplicity of infection for $24 \mathrm{~h}$ and treated with indicated cytokines for $24 \mathrm{~h}$. Luciferase activity was measured using OneGlo luciferase kit. Data are expressed as relative fold changes compared with corresponding control. c, $\mathbf{d}$ Western blot analysis of nuclear extracts from SVZ NSCS/NPCs for the nuclear translocation of non-classical (RelB, p52) and classical (p65) NFkB pathways. NSCs/NPCs were treated with indicated cytokines for $4 \mathrm{~h}$ before preparation of nuclear extracts. TNF: tumor necrosis factor; LT: lymphotoxin; IL: interleukin. Lamin AVC served as nuclear protein loading control 
in these cells. To validate this, we first determined whether LT $\beta R$ mRNA was expressed in cultured NSCs/ NPCs from adult mouse SVZ. The melting peak curve of RT-qPCR reaction attested to the presence of LT $\beta R$ mRNA expression in cultured NSCs/NPCs (Fig. 2a), which was significantly reduced after NSC/NPC differentiation for 1-3 days (Fig. 2a). Our previous study showed the $\mathrm{NFK}_{\mathrm{K}} \mathrm{B}$ reporter response of embryonic NSCs/NPCs to LT $\alpha 1 \beta 2$ [19], implying the presence of LT $\beta R$ expression during embryonic neurogenesis. To corroborate this and explore the potential role of LT $\beta \mathrm{R}$ mediated immune regulation during neural induction, we examined the expression pattern of LT $\beta R$ mRNA in ES cells, EB, and NSCs. We found that both ES cells and EB do express LT $\beta R$ mRNA as evidenced by the melting peak curve, but the expression was much lower than that in NSCs (Fig. 2b). The presence of LT $\beta R$ mRNA expression during adult neurogenesis was also validated by RT-qPCR analysis using the well-established neurogenic zones of adult mouse brains (Fig. 2c). To determine the presence of LT $\beta R$ protein expression in NSCs/ NPCs and brain tissues, we performed Western blot analysis using anti-LT $\beta R$ antibody, which specificity was verified using recombinant LT $\beta R$ protein (from AbCam, ab198752) and 1:20 antigen preabsorption (Fig. 3a). When using spleen tissue as a positive control, the protein expression of LT $\beta$ R was detected in adult brain tissues, with relatively higher levels in neurogenic regions such as dentate gyrus (DG) and olfactory bulb (OB) than the rest regions tested in the brain but

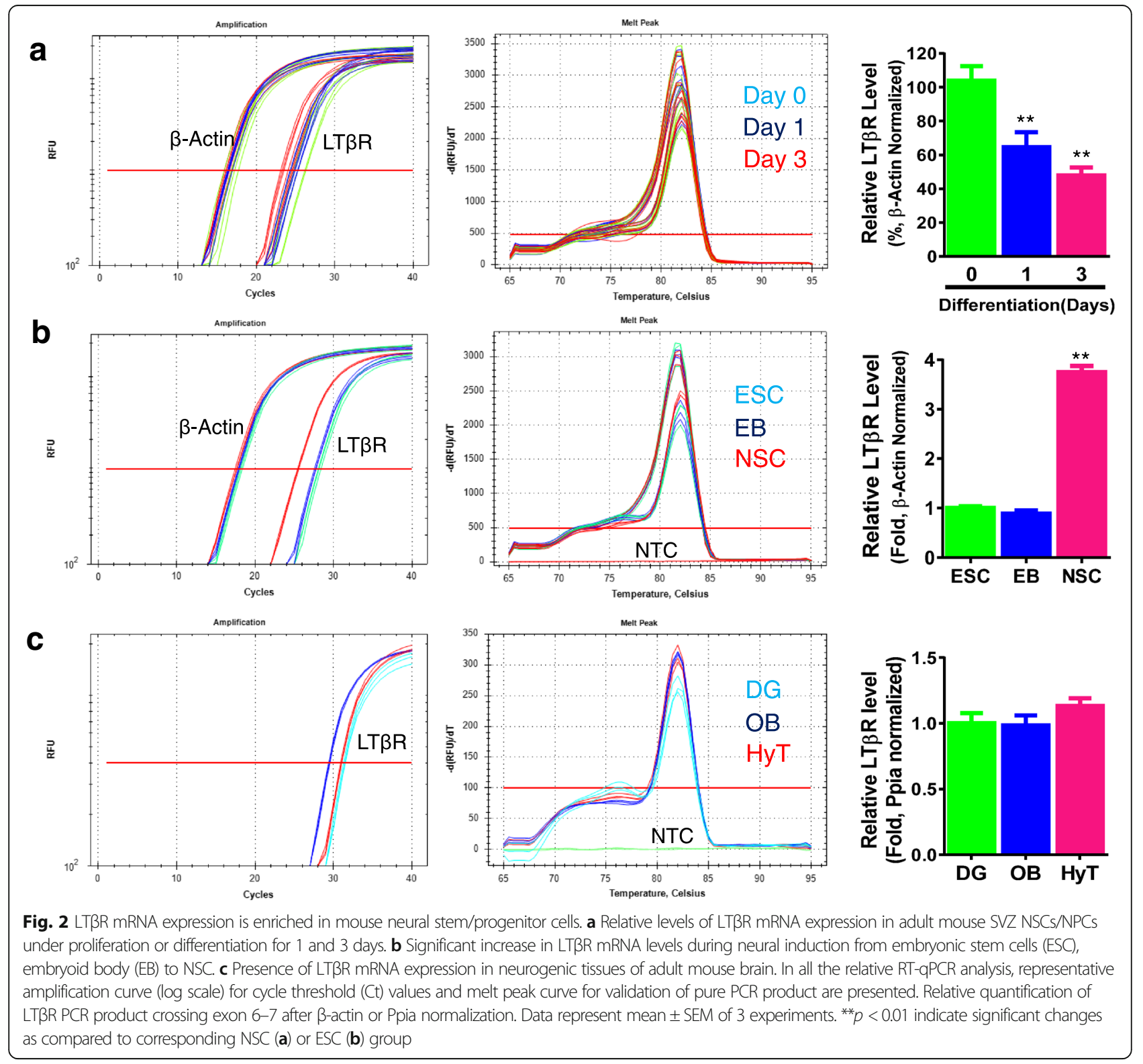


a

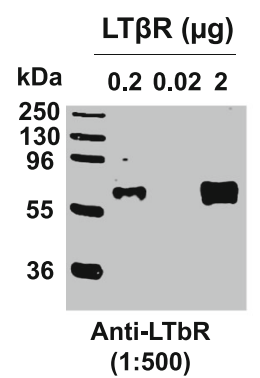

C

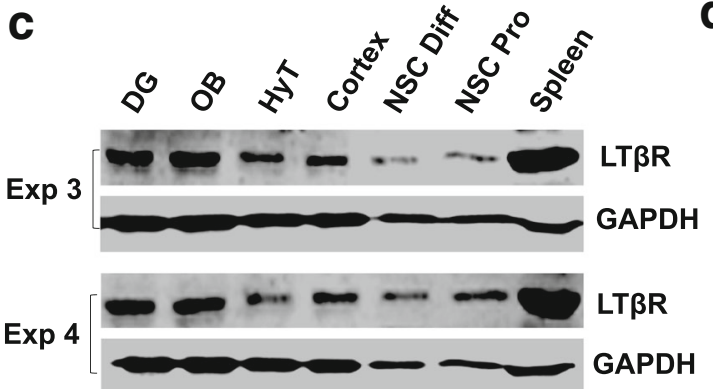

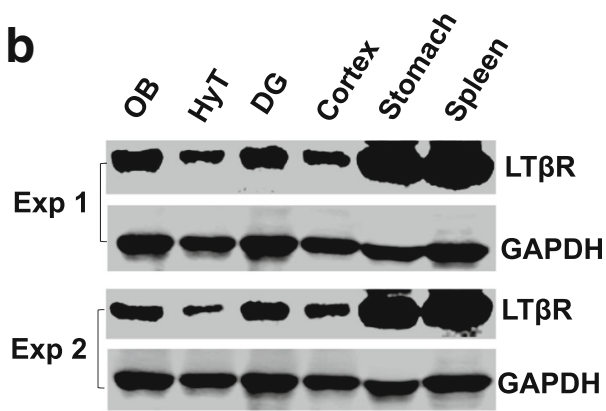

d

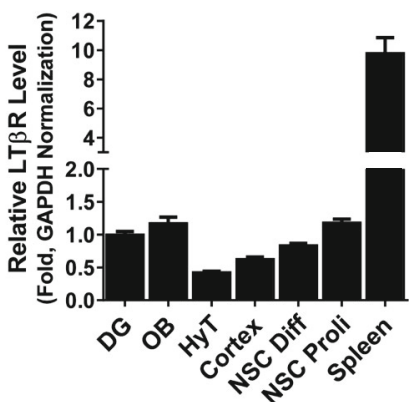

Fig. 3 Western blot analysis validates the presence of LT $\beta R$ protein expression in adult mouse SVZ NSCS/NPCS. a Specificity of anti-LTRR antibody. b, c Western blot analysis showing relative levels of LTRR protein expression in indicated brain regions. The spleen tissue was used as a positive control. $\mathbf{d}$ Bar graph showing the densitometry data representing mean \pm SEM of 4 independent experiments with relative fold changes as compared with the level in DG after GAPDH normalization. DG, dentate gyrus; OB, olfactory bulb; HyT, hypothalamus; Pro, proliferation; Diff, differentiation

significantly lower than that in the spleen tissue (Fig. 3b-d). LT $\beta$ R protein expression was also detectable in NSCs/NPCs cultured under proliferation or differentiation conditions (Fig. 3c, d). To address the regional and cellular distribution of LT $\beta R$ expression in the adult brain, we first analyzed the public in situ hybridization data in the sagittal brain sections of 8-week-old male C57/BL/6J mouse (http://mouse.brain-map.org) using LT $\beta R$ antisense probe generated by PCR with primer forward $5{ }^{\prime}$-cctcctactcggataccatctg-3' and reverse $5^{\prime}$-atcctagtgtctctgtctcggc- $3^{\prime}$. LT $\beta R$ mRNA was extensively expressed in the mouse brain (Fig. 4a-d), predominantly in the neurogenic zones (SGZ, SVZ), prefrontal cortex, hypothalamus, and cerebellum. In particular, the granular cells in DG showed very high expression (Fig. 4c). Then, we performed immunohistochemistry with anti-LT $\beta R$ antibody using series coronal sections of adult mouse brains. AntiMBP antibody was used to demarcate the white matter. The pattern of the regional distribution of LT $\beta R$-like immunoreactivity was similar to that of mRNA expression, namely predominant in the neurogenic zones such as SVZ, SGZ, hypothalamic arcuate nucleus, and amygdala (Fig. 4e, f). To validate the expression of LT $\beta R$ protein in NSCs/ NPCs of mouse neurogenic zones, we performed multilabeled immunofluorescent staining and confocal image analysis. We observed that LT $\beta R$-like immunoreactivity existed mainly in NeuN/Calretinin-positive neurons
(Fig. 5a) and Sox2/Nestin/GFAP-positive NSCs (Fig. 5b, c), but weakly expressed in Sox $2 /$ Nestin-positive NPCs (Fig. 5c) and DCX-positive neuroblasts (Fig. 5d). These data suggest that LT $\beta R$ is expressed at both mRNA and protein levels in NSCs both in vitro and in vivo.

\section{$\mathrm{LTa} \beta_{1} \beta_{2}$ inhibits neuronal differentiation and promotes glial lineage differentiation of NSCs/NPCs}

Various cytokines exhibit different and frequently opposite effects on neural lineage differentiation of NSCs/NPCs (see the "Background" section). To address whether LT $\beta R$ signaling affects neural lineage differentiation, we performed multilabeled immunocytochemistry with antibodies against lineage-specific markers Tuj1/DCX, GFAP, and MBP in cultured adult NSCs/NPCs (Fig. 6, Additional file 1: Figure S1a). During differentiation, the proportions of Tuj1-positive neurons and GFAP-positive astrocytes were increased while those of DCX-positive neuroblasts/neuronal cells and MBP-positive oligodendrocytes decreased in a time-dependent manner (Fig. 6). Treatment with $L T \alpha_{1} \beta_{2}$ at the initiation of neural differentiation increased the number at day 1 after treatment of those three lineage neural cells, including DCX-positive neuroblasts/neuronal cells, MBP-positive oligodendrocytes and GFAP-positive astrocytes (Fig. 6) but reduced the number of Tuj1-positive immature neurons (Fig. 6b). 


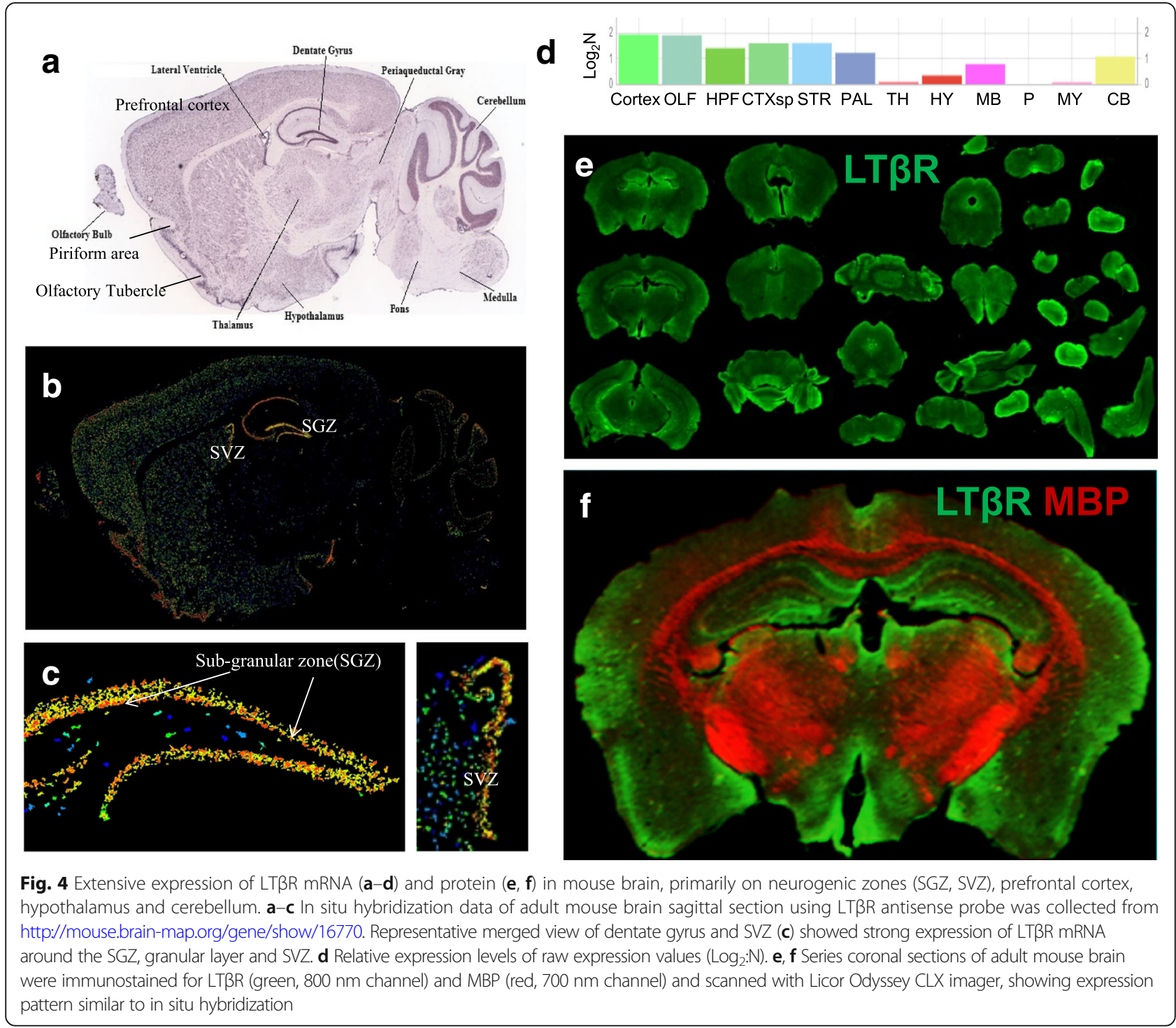

However, $L T \alpha_{1} \beta_{2}$ treatment caused diverse responses at the later stage of neural differentiation (day 3-6). It significantly reduced the number of DCX-positive neuroblasts/ neuronal cells (Fig. 6a, Additional file 1: Figure S1a) and Tuj1-positive immature neurons (Fig. 6b), but significantly increased the number of GFAP-positive astrocytes (Fig. 6c, Additional file 1: Figure S1a) and MBP-positive oligodendrocytes (Fig. 6d). To further validate the effects of $L T \alpha_{1} \beta_{2}$ on the neural lineage differentiation during embryonic neurogenesis, we treated E14 embryonic NSCs/NPCs with $\mathrm{LT} \alpha_{1} \beta_{2}$ in a similar way as that for adult NSCs/NPCs. We observed similar effects on neural lineage differentiation (Additional file 1: Figure S2). Pretreatment with NFkB activation inhibitor APQ dramatically blocked three lineage differentiation with complete loss of both DCX and MBP positive cells (Additional file 1: Figure S3a-c). Upon $L T \alpha_{1} \beta_{2}$ treatment, the increased astroglial lineage differentiation was prevented while neuronal lineage differentiation impairment was aggravated by APQ pretreatment (Additional file 1: Figure S3a-c). These data suggest that LT $\beta R$ signaling may be involved in the initiation of NSC differentiation into NPCs at the early stage while $\mathrm{NF}_{\kappa} \mathrm{B}$ inhibition prevents all three lineage differentiation. These findings are consistent with those from our previous studies demonstrating that NFkB signaling is essential to initiate NSC differentiation into NPCs [19] and maintain the late differentiation of three neural lineages $[19,60]$. At the later stages of neurogenesis, LT $\beta R$-mediated NFKB signaling preferentially stimulates glial lineage differentiation but impairs neuronal lineage differentiation. This is also consistent with other reports showing that TNF $\alpha$, IL$1 \beta$, IL- 6 and interferon- $\gamma$ promote glial lineage differentiation while inhibit neuronal differentiation of 


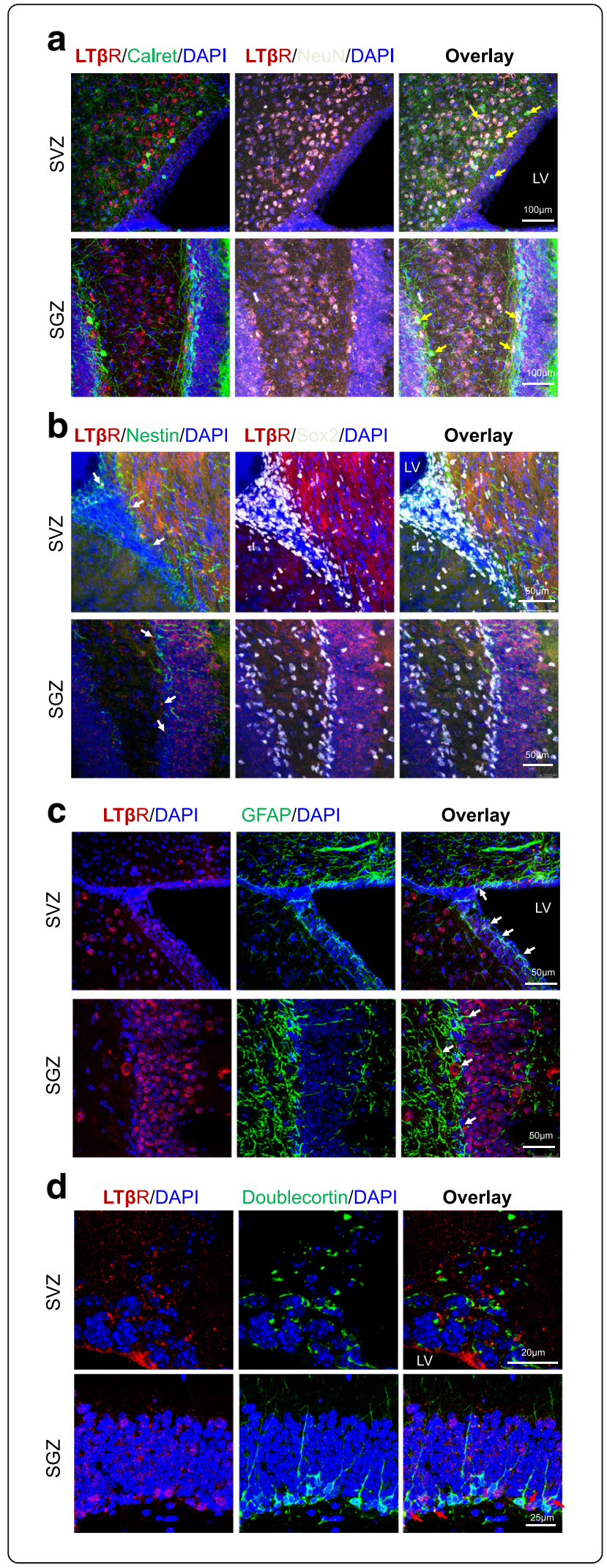

Fig. 5 Expression of LTßR-like immunoreactivity in subventricular zone (SVZ) and subgranular zone (SGZ) of adult mouse brain. Coronal brain sections underwent free-floating immunofluorescent immunohistochemistry with rabbit anti-LTßR antibody (red) together with goat anti-Calretinin (green) and mouse anti-NeuN (white) antibodies (a), chicken anti-Nestin (green) and goat anti-Sox2 (white) antibodies (b), chicken anti-GFAP (green) antibody (c), or goat anti-DCX (green) antibody (d) followed by corresponding Alexa Fluor ${ }^{\oplus}$ conjugated secondary antibodies and confocal image analysis. LT $\beta R$ is primarily expressed in $\mathrm{GFAP}^{+} / \mathrm{So} \times 2^{+} \mathrm{NSC}$ (white arrow), some neuroblasts (red arrow) and mature neurons (yellow arrow). LV, lateral ventricle; DG, dentate gyrus

NSCs/NPCs [28-44]. Surprisingly, Tuj1 expression was accumulated in the nucleus of most Tuj1-positive neurons after APQ pretreatment regardless whether or not with $\mathrm{LT} \alpha_{1} \beta_{2}$ treatment (Additional file 1: Figure S3a).

\section{Astroglial NFKB inactivation promotes neuronal lineage differentiation and inhibits astroglial lineage differentiation}

As shown above, NFkB signaling mediates three lineage differentiation in a stimulus-dependent manner, and cytokines preferentially drive differentiation toward glial lineage cells. To determine if astroglial $\mathrm{NFKB}$ signaling mediates LT-induced astroglial lineage differentiation, we used a transgenic (TG) mouse line expressing a dominant-negative ІкB $\alpha$ under the GFAP promoter [56]. This mouse line displays a deficit in adult neurogenesis [19] and learning/memory [71]. The specific inhibition of astroglial NFKB signaling was demonstrated in our previous studies [56, 19] and confirmed here. As shown in the Additional file 1: Figure S3d, the activation of $N F \kappa B$-luciferase reporter with $T N F \alpha$ and $L T \alpha_{1} \beta_{2}$ was significantly suppressed in TG NSCs/NPCs. Astroglial NFKB inactivation suppressed astroglial and oligodendrocytic lineage differentiation in TG NSCs/ NPCs as compared with that corresponding to WT NSCs/NPCs at days $1-3$ in the absence of $L T \alpha_{1} \beta_{2}$ treatment (Fig. 6c, d). LT-stimulated elevation of astrocytic differentiation was prevented completely by the transgenic inactivation of astroglial $\mathrm{NF \kappa B}$ signaling at days 1-6 (Fig. 6c). However, astroglial NFkB inactivation promoted LT-induced oligodendrocytic differentiation at the initial stage (day 1) but inhibited it at later stage (days 3-6) (Fig. 6d). Interestingly, the constitutive neuronal differentiation was significantly improved in TG NSCs/NPCs, and LT-induced inhibition of neuronal differentiation was reversed by the astroglial NFkB inactivation at days 1-6 (Fig. 6a, b). These data suggest that selective inhibition of $\mathrm{NFKB}$ signaling in GFAPpositive cells promotes neuronal lineage differentiation while inhibits glial lineage differentiation. 

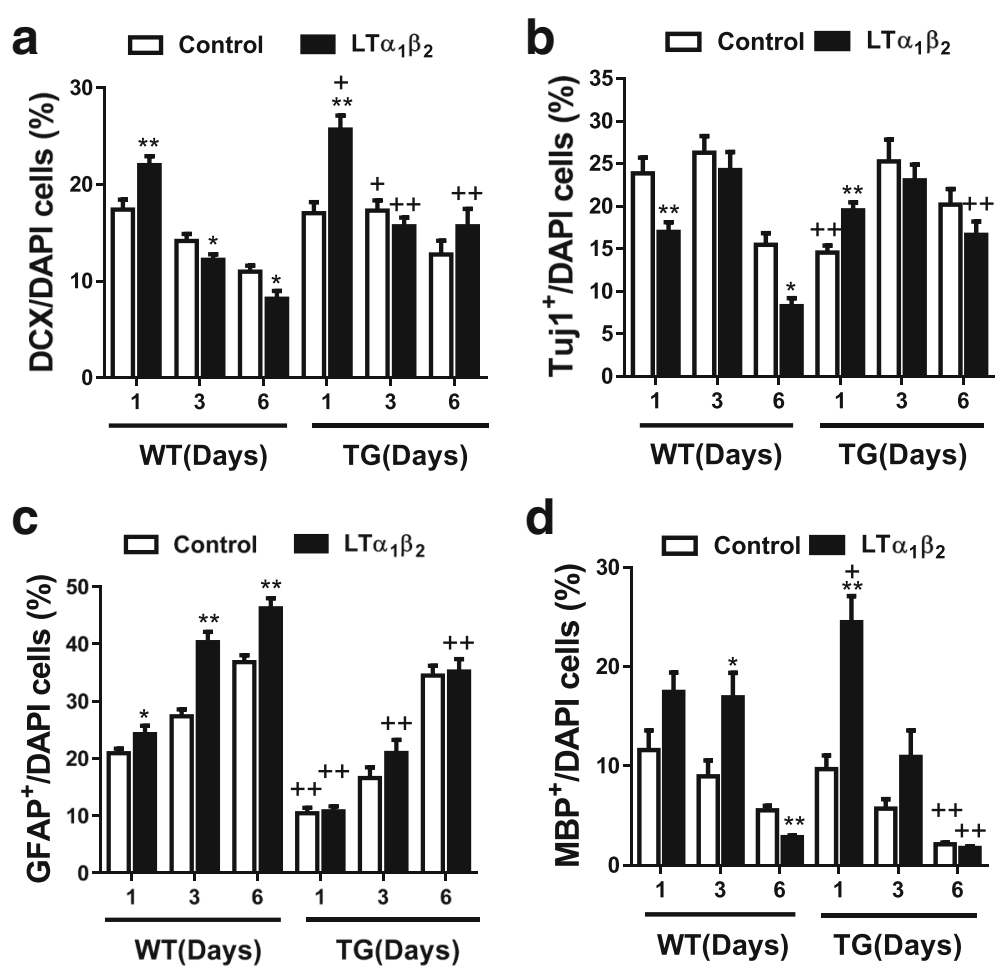

Fig. 6 Transgenic inactivation of astroglial NFKB pathway inhibits constitutive and LT-induced astroglial lineage differentiation but favors neuronal lineage differentiation. a, b Quantitative analysis of neuronal lineage differentiation determined by Tuj1 (immature neurons) and DCX (neuroblasts). c, d Quantitative analysis of glial lineage differentiation determined by GFAP (astrocytes) or MBP (Oligodendrocytes). Multi-labeled fluorescent immunocytochemistry and confocal image analysis were performed at 1-6 days of differentiation from SVZ NSCS/NPCs of littermated wild-type (WT) and GFAP-dnlkBa transgenic mice (TG) in the presence or absence of $\mathrm{LTa}_{1} \beta_{2}(100 \mathrm{ng} / \mathrm{ml})$. The percentage of Tuj $1^{+}$or DCX ${ }^{+}$(neurons/neuroblasts), GFAP ${ }^{+}$(astrocytes) and $\mathrm{MBP}^{+}$ (oligodendrocytes) over DAPI-stained cells per field under $\times 40$ objective was determined. Data from 8 fields per duplicate well of each experiment containing littermated WT and TG NSCS/NPCs in 16-well chamberslide from 3 paired animals were statistically analyzed by two-tailed student $t$-test. ${ }^{*} p<0.05$ and ${ }^{* *} p<0.01$ indicate significant changes in $\mathrm{LTa}_{1} \beta_{2}$ treatment as compared to corresponding control. ${ }^{+} p<0.05$ and ${ }^{++} p<0.01$ indicate significant changes in the TG group as compared with corresponding WT group

\section{Discussion}

The salient finding in this study is the first identification of LT $\beta \mathrm{R}$ signaling and function in NSCs/NPCs both in vitro and in vivo. Activation of LT $\beta R$ signaling promotes astroglial and oligodendrocytic, but inhibits neuronal, lineage differentiation. Astroglial inactivation of $\mathrm{NF}_{\mathrm{B}} \mathrm{B}$ signaling compromises astroglial, but promotes neuronal, lineage differentiation (Fig. 7). Our findings suggest that neurogenesis may be deliberately regulated by the adaptive immunity and inflammatory responses via LT $\beta R$ signaling.

Intensive attention has been paid on inflammatory mediators including cytokines, chemokines, growth factors, and adhesion molecules due to their critical and diverse roles in the pathophysiology related to the disorders of nervous system [21, 22, 72-74]. It is well known that most inflammatory mediators regulate $\mathrm{NF}_{\kappa} \mathrm{B}$ signaling. $N_{\kappa} B$ signaling has been widely shown to regulate self-renewal, proliferation, and apoptosis of NSCs/NPCs; migration of neuroblasts; and maturation and plasticity of nascent neurons [73, 75-78]. However, different cytokines may exhibit various and, sometimes, opposite effects on neurogenesis. The current study provides novel evidence to support the critical role of LT $\beta R$ signaling in regulating neurogenesis. LT $\beta R$ signaling has long been investigated in lymphoid organogenesis [79], lymphangiogenesis [53-55] and tumorigenesis [80-84]. It involves in many inflammatory processes relative to chronic inflammatory diseases [55] including brain tertiary lymph organ [85]. Although several inflammatory mediators have been shown to regulate neurogenesis [60], no report is seen in the literature up-to-date on the potential role of LT and its receptor signaling in neurogenesis. During our investigation on NFKB signaling in initiating NSC differentiation, we surprisingly found that LT $\alpha 1 \beta 2$ induces potent activation of $\mathrm{NFKB}$ signaling in embryonic/neonatal NSCs, with similar potency to TNF $\alpha$ [19]. This interesting observation suggests that lymphotoxin-mediated immune responses influences embryonic/neonatal neurogenesis [59, 86]. This also directed us to explore further the effect of 


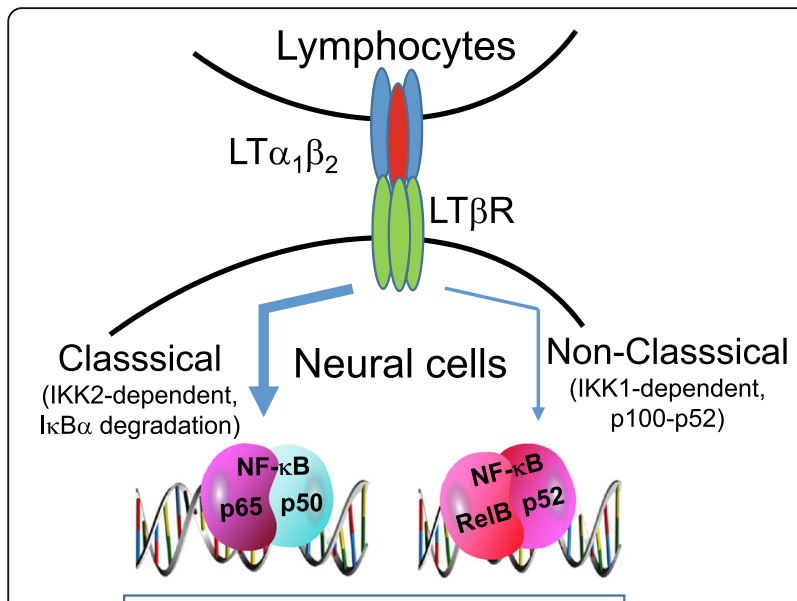

\section{Target gene expression}

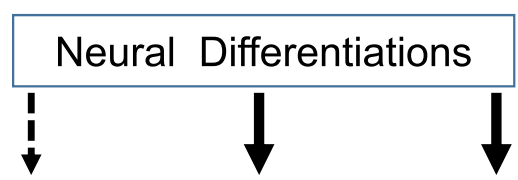

\section{Neurons Astrocytes Oligodendrocytes}

Fig. 7 Diagram illustrating the stronger classical and weaker nonclassical NFKB signaling pathways induced by $L \mathrm{Ta}_{1} \beta_{2}$ stimulation in mouse brain neural stem/progenitor cells, resulting in promotion of glial lineage differentiation and inhibition of neuronal lineage differentiation. Selective astroglial inactivation of NFKB signaling inhibits astroglial lineage differentiation while promotes neuronal lineage differentiation

LT $\beta R$ signaling on adult neurogenesis [9, 87]. We demonstrated strong evidence that LT $\beta R$ signaling is enriched in NSCs during neural induction and neurogenesis. Through in situ hybridization and immunohistochemistry, the presence of extensive expression of LTbR in most neurons were identified, indicating a potential essential role in regulating neuronal plasticity and yet to be determined functions. Our observation also suggests that lymphocyte-derived LT can directly influence NSCs and neurons via its unique receptor $L T \beta R$. It is important to understand how the direct communication between lymphocytes and neural cells takes place and how immune system regulates nervous system in both physiological and pathological conditions $[14,59,86]$. The preferential promotion of glial lineage differentiation by LT $\beta$ R signaling may contribute to neurodegeneration and repair process during nervous system injury and diseases. In multiple sclerosis animal models, LT $\beta R$ signaling plays a detrimental effect on both demyelination and remyelination via $\mathrm{T}$ cells $[88,89]$ and/or local astrocytes/microglia [90]. Inhibition of LT $\beta R$ signaling might be a better candidate biotherapeutics for inflammatory demyelinating diseases due to its dual benefits in both delaying demyelination and promoting remyelination [90].

There are three $\mathrm{NF}_{\kappa} \mathrm{B}$ activation pathways described: classical (canonical), non-classical (non-canonical, alternative), and atypical pathways [91]. LT $\beta R$ activation engages preferentially the non-classical pathway in immune systems and other cell types [6166]. Our studies in NSCs/NPCs demonstrate that LT $\beta R$ preferentially activates the classical pathway, which is supported by the following experimental evidence: (1) $L T \alpha_{1} \beta_{2}$ induced activation of NFKB-luciferase reporter in a similar manner as TNF $\alpha$ and IL- $1 \beta$; (2) LT $\alpha_{1} \beta_{2}$ dramatically stimulates p65 phosphorylation [84], I $\mathrm{KB} \alpha$ degradation [84], and p65 nuclear translocation (Fig. 1d); (3) Transgenic dnIkB $\alpha$ expression in GFAP-positive cells blocked LT-induced astroglial differentiation; (4) LIGHT did not activate NFkBluciferase reporter although it has widely been shown to bind to LT $\beta R$ in other cell types $[67,68,92]$.

NSC transplantation has been extensively studied in both animal models and clinical trials [93, 94]. A major barrier in the therapeutic application for NSC transplantation is the preferential astrogliogenesis in vivo when NSCs/NPCs encounter the debilitated microenvironmental niches where abundant inflammatory cytokines, including NFKB signaling stimulators, may exist [95-98]. A selective blockade of astrogliogenesis and promotion of neuronal differentiation would be an important strategy for NSC transplantation. Our findings that astroglial NFKB inactivation suppressed LT-induced astrogliogenesis but promoted neuronal lineage differentiation may help approach to establishing a novel therapeutic strategy. Supportively, a previous study using lentivirus-mediated IкB $\alpha$ gene delivery in cultured NSCs/ NPCs demonstrated that NFkB inhibition promotes survival and neuronal differentiation of transplanted NSCs [99].

\section{Conclusions}

In conclusion, this is the first report to show LT $\beta R$ effects on regulating neural differentiation by demonstrating evidence of the expression and function of LT $\beta \mathrm{R}$ signaling in neural stem/progenitor cells. Activation of LT $\beta R$ signaling promotes lineage differentiation of neural stem/progenitor cells preferentially through classical NFKB pathway. Understanding neuroinflammatory responses and neuroimmunity modulating neurogenesis might help understand the underlying pathophysiology relative to neuro-plasticity and relevant neurological disorders. LT $\beta R$ may become a potential therapeutic target in the future in treating various neurodevelopmental and neurodegenerative diseases $[14,16]$.

\section{Additional file}

Additional file 1: Figure S1. Representative micrographs showing transgenic inactivation of astroglial NFKB pathway inhibits constitutive and LT-induced astroglial lineage differentiation but favors neuronal 
lineage differentiation in SVZ NSCS/NPCs from littermated wild-type (WT, a) and GFAP-dnlkBa transgenic mice $(\mathrm{TG}, \mathrm{b})$. At the $1 \mathrm{st}$, 3rd and 6 th day of differentiation, GFAP (green) and DCX (red)-positive cells were determined by multi-labeled fluorescent immunocytochemistry and confocal image analysis. Scale bars $=50 \mu \mathrm{m}$. Figure $\mathbf{S} \mathbf{2}$. $\mathrm{LTa}_{1} \beta_{2}$ promoted astrocytic and oligodendrocytic differentiation but inhibited neuronal differentiation in mouse embryonic NSCs/NPCs. (a, b) Representative micrographs showing 3 lineage differentiation of cultured NSCS/NPCs from E14 mouse brain. White arrows (a) indicate representative Tuj1-positive typical neurons with various degrees of neurites and branches. The small red dots in GFAP staining (b) derived from non-specific debris for chicken anti-GFAP antibody. Scale bars $=75 \mu \mathrm{m}$. (c) Quantitative analysis of lineage differentiation after treatment with $\mathrm{LTa}_{1} \beta_{2}$. Figure S3. Effects of NFKB inhibition on neural lineage differentiation in mouse NSCS/NPCs. (a, b) Representative micrographs showing complete loss of DCX (neuroblasts) and MBP (oligodendrocytes) and dramatic reduction of Tuj1 (immature neurons) and GFAP (astrocytes) after NFkB activation inhibitor APQ (10 $\mu \mathrm{M})$ pretreatment 30 min before $\mathrm{LTa}_{1} \beta_{2}(100 \mathrm{ng} / \mathrm{ml})$ treatment under differentiation condition for 3 days. White arrows indicate representative Tuj1-positive typical neurons and green arrows show the nuclear location of Tuj1 expression (a). Scale bars $=75 \mathrm{\mu m}$. (c) Quantitative analysis of Tuj 1 and GFAP positive cells after $L T a_{1} \beta_{2}$ treatment in the presence or absence of APQ. (d) Adenovirus-mediated NFKB-firefly-luciferase reporter assay showing a significant reduction in cytokine-induced NFKB activation in SVZ NSCS/NPCs from TG mice. Data represent mean $\pm \mathrm{SEM} .{ }^{*} p<0.05$ and ${ }^{* *} p<0.01$ indicate significant changes after cytokine treatment as compared to corresponding control group. $++p<0.01$ indicates significant decrease in APQ group compared with corresponding DMSO group. (PPTX $5201 \mathrm{~kb}$ )

\section{Abbreviations}

APQ: 6-Amino-4-(4-phenoxyphenylethylamino)quinazoline; BAFF: B-cell activating factor; bFGF: Basic fibroblast growth factor; DCX: Doublecortin; dnlkBa: Dominant-negative inhibitor of NFkB a; EB: Embryoid body; EGF: Epidermal growth factor; ESC: Embryonic stem cells; GFAP: Glial fibrillary

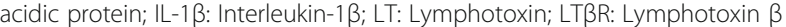
receptor; MBP: Myelin basic protein; NFKB: Nuclear factor kappa B; NPC: Neural progenitor cells; NSC: Neural stem cells; PBS: Phosphate-buffered saline; RT-PCR: Reverse transcription-polymerase chain reaction; SGZ: Subgranular zone; SVZ: Subventricular zone; TLR: Toll-like receptor; TNFa: Tumor necrosis factor-a; Tuj1: Neuron-specific class III $\beta$-tubulin

\section{Acknowledgements}

Not applicable.

\section{Author contributions}

$W H, Y C$, JL, and JB conceived the project. $W H, X X, R P$, and $Y Z$ designed the experiments. XX, PS, YZ, and TZ performed reporter assay and Western blot $X X, R P, P S, F L$, and $M X$ performed the cell culture, immunohistochemistry, confocal imaging, and quantitative analysis. XX, PS, FL, and MX performed RT-qPCR analysis. $W H, X X$, and $Y C$ analyzed the data and prepared figures. $\mathrm{WH}, \mathrm{XX}$, and RP wrote and edited the manuscript. All authors read and approved the final manuscript.

\section{Funding}

This work was supported by the National Institute of Health R01-MH101041 and R01-DK075964 (WH)

\section{Availability of data and materials}

The data and research materials are available from the corresponding authors upon a reasonable written request.

\section{Ethics approval}

All procedures for animal usage were complied with the guidelines of the National Institutes of Health and approved by the Institutional Animal Care and Use Committee (IACUC) at Temple University (Approval number 4324).

\section{Consent for publication}

Not applicable.

\section{Competing interests}

The authors declare that they have no competing interests.

\section{Publisher's Note}

Springer Nature remains neutral with regard to jurisdictional claims in published maps and institutional affiliations.

\section{Author details}

'Department of Neurosurgery, The Second Affiliated Hospital of Chongqing Medical University, Chongqing 400010, China. ${ }^{2}$ Center for Metabolic Disease Research, Department of Pathology and Laboratory Medicine, Temple University Lewis Katz School of Medicine, 3500 N Broad Street, Philadelphia, PA 19140, USA. ${ }^{3}$ Department of Neurology, Temple University Lewis Katz School of Medicine, 3401 N Broad Street, Philadelphia, PA, USA. ${ }^{4}$ Department of Biology, Drexel University, Philadelphia, PA, USA.

Received: 27 July 2017 Accepted: 22 January 2018

Published online: 20 February 2018

\section{References}

1. Callan MA, Zarnescu DC. Heads-up: new roles for the fragile X mental retardation protein in neural stem and progenitor cells. Genesis. 2011;49(6): 424-40

2. Kishi N, Macklis JD. MeCP2 functions largely cell-autonomously, but also non-cell-autonomously, in neuronal maturation and dendritic arborization of cortical pyramidal neurons. Exp Neurol. 2010;222(1):51-8.

3. Heanue TA, Pachnis V. Enteric nervous system development and Hirschsprung's disease: advances in genetic and stem cell studies. Nat Rev Neurosci. 2007:8(6):466-79.

4. Schafer $\mathrm{KH}$, Micci MA, Pasricha PJ. Neural stem cell transplantation in the enteric nervous system: roadmaps and roadblocks. Neurogastroenterol Motil. 2009;21(2):103-12.

5. Ma DK, Bonaguidi MA, Ming GL, Song H. Adult neural stem cells in the mammalian central nervous system. Cell Res. 2009;19(6):672-82.

6. Vaillend C, Poirier R, Laroche S. Genes, plasticity and mental retardation. Behav Brain Res. 2008;192(1):88-105.

7. Mu Y, Gage FH. Adult hippocampal neurogenesis and its role in Alzheimer's disease. Mol Neurodegener. 2011;6:85.

8. van den Berge SA, van Strien ME, Korecka JA, Dijkstra AA, Sluijs JA, Kooijman L, Eggers R, De Filippis L, Vescovi AL, Verhaagen J, et al. The proliferative capacity of the subventricular zone is maintained in the parkinsonian brain. Brain. 2011;134(Pt 11):3249-63.

9. Huehnchen P, Prozorovski T, Klaissle P, Lesemann A, Ingwersen J, Wolf SA, Kupsch A, Aktas O, Steiner B. Modulation of adult hippocampal neurogenesis during myelin-directed autoimmune neuroinflammation. Glia. 2011:59(1):132-42

10. Tepavcevic V, Lazarini F, Alfaro-Cervello C, Kerninon C, Yoshikawa K, Garcia-Verdugo JM, Lledo PM, Nait-Oumesmar B, Baron-Van Evercooren A. Inflammation-induced subventricular zone dysfunction leads to olfactory deficits in a targeted mouse model of multiple sclerosis. J Clin Invest. 2011;121(12):4722-34.

11. Conti L, Cattaneo E. Neural stem cell systems: physiological players or in vitro entities? Nat Rev Neurosci. 2010;11(3):176-87.

12. Zhao C, Deng W, Gage FH. Mechanisms and functional implications of adult neurogenesis. Cell. 2008;132(4):645-60.

13. Xiong $X Y$, Liu L, Yang QW. Functions and mechanisms of microglia/ macrophages in neuroinflammation and neurogenesis after stroke. Prog Neurobiol. 2016:142:23-44

14. de Miranda AS, Zhang CJ, Katsumoto A, Teixeira AL. Hippocampal adult neurogenesis: does the immune system matter? J Neurol Sci. 2017:372:482-95.

15. Sochocka M, Diniz BS, Leszek J. Inflammatory response in the CNS: friend or foe? Mol Neurobiol. 2016;54(10):8071-89.

16. Herkenham M, Kigar SL. Contributions of the adaptive immune system to mood regulation: mechanisms and pathways of neuroimmune interactions. Prog Neuro-Psychopharmacol Biol Psychiatry. 2017;79(Pt A):49-57.

17. Rolls A, Shechter R, London A, Ziv Y, Ronen A, Levy R, Schwartz M. Toll-like receptors modulate adult hippocampal neurogenesis. Nat Cell Biol. 2007; 9(9):1081-8

18. Denis-Donini S, Dellarole A Crociara P, Francese MT, Bortolotto V Quadrato G, Canonico PL, Orsetti M, Ghi P, Memo M, et al. Impaired adult neurogenesis associated with short-term memory defects in NF-kappaB p50-deficient mice. J Neurosci. 2008;28(15):3911-9. 
19. Zhang Y, Liu J, Yao S, Li F, Xin L, Lai M, Bracchi-Ricard V, Xu H, Yen W, Meng W, et al. Nuclear factor kappa B signaling initiates early differentiation of neural stem cells. Stem Cells. 2012;30(3):510-24.

20. Yirmiya R, Goshen I. Immune modulation of learning, memory, neural plasticity and neurogenesis. Brain Behav Immun. 2011;25(2):181-213.

21. Das S, Basu A. Inflammation: a new candidate in modulating adult neurogenesis. J Neurosci Res. 2008;86(6):1199-208.

22. Whitney NP, Eidem TM, Peng H, Huang Y, Zheng JC. Inflammation mediates varying effects in neurogenesis: relevance to the pathogenesis of brain injury and neurodegenerative disorders. J Neurochem. 2009; 108(6):1343-59.

23. Scholzke MN, Rottinger A, Murikinati S, Gehrig N, Leib C, Schwaninger M. TWEAK regulates proliferation and differentiation of adult neural progenitor cells. Mol Cell Neurosci. 2011;46(1):325-32.

24. Lou SJ, Gu P, Xu H, Xu XH, Wang MW, He C, Lu CL. Effect of tumor necrosis factor-alpha on differentiation of mesencephalic neural stem cells and proliferation of oligodendrocytes in the rat. Sheng Li Xue Bao. 2003:55(2):183-6.

25. Widera D, Mikenberg I, Kaus A, Kaltschmidt C, Kaltschmidt B. Nuclear factorkappaB controls the reaggregation of $3 \mathrm{D}$ neurosphere cultures in vitro. Eur Cell Mater. 2006;11:76-84. discussion 85

26. Kajiwara K, Ogata S, Tanihara M. Promotion of neurite outgrowth from fetal hippocampal cells by TNF-alpha receptor 1-derived peptide. Cell Transplant. 2005;14(9):665-72.

27. Keohane A, Ryan S, Maloney E, Sullivan AM, Nolan YM. Tumour necrosis factoralpha impairs neuronal differentiation but not proliferation of hippocampal neural precursor cells: role of Hes1. Mol Cell Neurosci. 2010;43(1):127-35.

28. Wong G, Goldshmit Y, Turnley AM. Interferon-gamma but not TNF alpha promotes neuronal differentiation and neurite outgrowth of murine adult neural stem cells. Exp Neurol. 2004;187(1):171-7.

29. Ideguchi M, Shinoyama M, Gomi M, Hayashi H, Hashimoto N, Takahashi J. Immune or inflammatory response by the host brain suppresses neuronal differentiation of transplanted ES cell-derived neural precursor cells. J Neurosci Res. 2008;86(9):1936-43.

30. Ricci-Vitiani L, Casalbore P, Petrucci G, Lauretti L, Montano N, Larocca LM, Falchetti ML, Lombardi DG, Gerevini VD, Cenciarelli C, et al. Influence of local environment on the differentiation of neural stem cells engrafted onto the injured spinal cord. Neurol Res. 2006;28(5):488-92.

31. Peng H, Whitney N, Wu Y, Tian C, Dou H, Zhou Y, Zheng J. HIV-1-infected and/or immune-activated macrophage-secreted TNF-alpha affects human fetal cortical neural progenitor cell proliferation and differentiation. Glia. 2008;56(8):903-16.

32. Johansson S, Price J, Modo M. Effect of inflammatory cytokines on major histocompatibility complex expression and differentiation of human neural stem/progenitor cells. Stem Cells. 2008;26(9):2444-54.

33. Mukaino M, Nakamura M, Okada S, Toyama Y, Liu M, Okano H. Role of IL-6 in regulation of inflammation and stem cell differentiation in CNS trauma. Nihon Rinsho Meneki Gakkai Kaishi. 2008;31(2):93-8.

34. Nakanishi M, Niidome T, Matsuda S, Akaike A, Kihara T, Sugimoto H. Microglia-derived interleukin-6 and leukaemia inhibitory factor promote astrocytic differentiation of neural stem/progenitor cells. Eur J Neurosci. 2007;25(3):649-58.

35. Okano H. Adult neural stem cells and central nervous system repair. Ernst Schering Res Found Workshop. 2006;60:215-28.

36. Islam O, Gong X, Rose-John S, Heese K. Interleukin-6 and neural stem cells: more than gliogenesis. Mol Biol Cell. 2009;20(1):188-99.

37. Goshen I, Yirmiya R. Interleukin-1 (IL-1): a central regulator of stress responses. Front Neuroendocrinol. 2009;30(1):30-45.

38. Koo JW, Duman RS. IL-1 beta is an essential mediator of the antineurogenic and anhedonic effects of stress. Proc Natl Acad Sci U S A. 2008:105(2):751-6.

39. Ben Menachem-Zidon O, Goshen I, Kreisel T, Ben Menahem Y, Reinhartz E, Ben Hur T, Yirmiya R. Intrahippocampal transplantation of transgenic neural precursor cells overexpressing interleukin-1 receptor antagonist blocks chronic isolation-induced impairment in memory and neurogenesis. Neuropsychopharmacology. 2008;33(9):2251-62.

40. Goshen I, Kreisel T, Ben-Menachem-Zidon O, Licht T, Weidenfeld J, Ben-Hur T, Yirmiya R. Brain interleukin-1 mediates chronic stress-induced depression in mice via adrenocortical activation and hippocampal neurogenesis suppression. Mol Psychiatry. 2008;13(7):717-28.

41. Koo JW, Russo SJ, Ferguson D, Nestler EJ, Duman RS. Nuclear factor-kappaB is a critical mediator of stress-impaired neurogenesis and depressive behavior. Proc Natl Acad Sci U S A. 2010;107(6):2669-74.
42. Green HF, Treacy E, Keohane AK, Sullivan AM, O'Keeffe GW, Nolan YM. A role for interleukin-1beta in determining the lineage fate of embryonic rat hippocampal neural precursor cells. Mol Cell Neurosci. 2012;49(3):311-21.

43. Lum M, Croze E, Wagner C, McLenachan S, Mitrovic B, Turnley AM. Inhibition of neurosphere proliferation by IFNgamma but not IFNbeta is coupled to neuronal differentiation. J Neuroimmunol. 2009;206(1-2):32-8.

44. Ben-Hur T, Ben-Menachem O, Furer V, Einstein O, Mizrachi-Kol R, Grigoriadis $\mathrm{N}$. Effects of proinflammatory cytokines on the growth, fate, and motility of multipotential neural precursor cells. Mol Cell Neurosci. 2003;24(3):623-31.

45. Hohmann HP, Remy R, Poschl B, van Loon AP. Tumor necrosis factors-alpha and -beta bind to the same two types of tumor necrosis factor receptors and maximally activate the transcription factor NF-kappa B at low receptor occupancy and within minutes after receptor binding. J Biol Chem. 1990;265(25):15183-8.

46. Browning JL, Dougas I, Ngam-ek A, Bourdon PR, Ehrenfels BN, Miatkowski K, Zafari M, Yampaglia AM, Lawton P, Meier W, et al. Characterization of surface lymphotoxin forms. Use of specific monoclonal antibodies and soluble receptors. J Immunol. 1995;154(1):33-46.

47. Crowe PD, VanArsdale TL, Walter BN, Ware CF, Hession C, Ehrenfels B, Browning JL, Din WS, Goodwin RG, Smith CA. A lymphotoxin-beta-specific receptor. Science. 1994;264(5159):707-10.

48. Wu W, Shi Y, Xia H, Chai Q, Jin C, Ren B, Zhu M. Epithelial LTbetaR signaling controls the population size of the progenitors of medullary thymic epithelial cells in neonatal mice. Sci Rep. 2017;7:44481.

49. Wege AK, Huber B, Wimmer N, Mannel DN, Hehlgans T. LTbetaR expression on hematopoietic cells regulates acute inflammation and influences maturation of myeloid subpopulations. Innate Immun. 2014;20(5):461-70.

50. Wimmer N, Huber B, Barabas N, Rohrl J, Pfeffer K, Hehlgans T. Lymphotoxin beta receptor activation on macrophages induces cross-tolerance to TLR4 and TLR9 ligands. J Immunol. 2012;188(7):3426-33.

51. Huber $C$, Thielen $C$, Seeger $H$, Schwarz $P$, Montrasio F, Wilson MR, Heinen E, Fu YX, Miele G, Aguzzi A. Lymphotoxin-beta receptor-dependent genes in lymph node and follicular dendritic cell transcriptomes. J Immunol. 2005;174(9):5526-36.

52. Mackay F, Majeau GR, Lawton P, Hochman PS, Browning JL. Lymphotoxin but not tumor necrosis factor functions to maintain splenic architecture and humoral responsiveness in adult mice. Eur J Immunol. 1997;27(8):2033-42.

53. Ruddle NH. Lymphatic vessels and tertiary lymphoid organs. J Clin Invest. 2014;124(3):953-9.

54. Tang H, Zhu M, Qiao J, Fu YX. Lymphotoxin signalling in tertiary lymphoid structures and immunotherapy. Cell Mol Immunol. 2017;14(10):809-18.

55. Ruddle NH. High endothelial venules and lymphatic vessels in tertiary lymphoid organs: characteristics, functions, and regulation. Front Immunol. 2016;7:491.

56. Brambilla R, Bracchi-Ricard V, Hu WH, Frydel B, Bramwell A, Karmally S, Green EJ, Bethea JR. Inhibition of astroglial nuclear factor kappaB reduces inflammation and improves functional recovery after spinal cord injury. J Exp Med. 2005;202(1):145-56.

57. Zhang Y, Hu W. Mouse enteric neuronal cell culture. Methods Mol Biol. 2013;1078:55-63.

58. Illes S, Theiss S, Hartung HP, Siebler M, Dihne M. Niche-dependent development of functional neuronal networks from embryonic stem cell-derived neural populations. BMC Neurosci. 2009:10:93.

59. Di Marco B, Bonaccorso CM, Aloisi E, D'Antoni S, Catania MV. Neuroinflammatory mechanisms in developmental disorders associated with intellectual disability and autism spectrum disorder: a neuro- immune perspective. CNS Neurol Disord Drug Targets. 2016;15(4):448-63.

60. Zhang Y, Hu W. NFkappaB signaling regulates embryonic and adult neurogenesis. Front Biol (Beijing). 2012;7(4):277-91.

61. Weidemann A, Lovas A, Rauch A, Andreas N, von Maltzahn J, Riemann M, Weih F. Classical and alternative NF-kappaB signaling cooperate in regulating adipocyte differentiation and function. Int J Obes. 2016;40(3):452-9.

62. Lotzer K, Dopping S, Connert S, Grabner R, Spanbroek R, Lemser B, Beer M, Hildner M, Hehlgans T, van der Wall M, et al. Mouse aorta smooth muscle cells differentiate into lymphoid tissue organizer-like cells on combined tumor necrosis factor receptor-1/lymphotoxin beta-receptor NF-kappaB signaling. Arterioscler Thromb Vasc Biol. 2010;30(3):395-402.

63. Lovas A, Radke D, Albrecht D, Yilmaz ZB, Moller U, Habenicht AJ, Weih F. Differential RelA- and RelB-dependent gene transcription in LTbetaRstimulated mouse embryonic fibroblasts. BMC Genomics. 2008;9:606.

64. Yilmaz ZB, Weih DS, Sivakumar V, Weih F. RelB is required for Peyer's patch development: differential regulation of p52-RelB by lymphotoxin and TNF. EMBO J. 2003;22(1):121-30 
65. Dejardin E, Droin NM, Delhase M, Haas E, Cao Y, Makris C, Li ZW, Karin M, Ware CF, Green DR. The lymphotoxin-beta receptor induces different patterns of gene expression via two NF-kappaB pathways. Immunity. 2002:17(4):525-35.

66. Benezech C, Mader E, Desanti G, Khan M, Nakamura K, White A, Ware CF, Anderson G, Caamano JH. Lymphotoxin-beta receptor signaling through NF-kappaB2-RelB pathway reprograms adipocyte precursors as lymph node stromal cells. Immunity. 2012;37(4):721-34.

67. Kim YS, Nedospasov SA, Liu ZG. TRAF2 plays a key, nonredundant role in LIGHT-lymphotoxin beta receptor signaling. Mol Cell Biol. 2005;25(6):2130-7.

68. Wang J, Fu YX. The role of LIGHT in T cell-mediated immunity. Immunol Res. 2004;30(2):201-14

69. Hehlgans T, Muller P, Stopfer P, Mannel DN. Activation of the lymphotoxinbeta receptor induces NFkappaB-dependent interleukin-6 and MIP-2 secretion in mouse fibrosarcoma cells. Eur Cytokine Netw. 2003;14(2):103-7.

70. Onder L, Danuser R, Scandella E, Firner S, Chai Q, Hehlgans T, Stein JV, Ludewig B. Endothelial cell-specific lymphotoxin-beta receptor signaling is critical for lymph node and high endothelial venule formation. J Exp Med. 2013;210(3):465-73.

71. Bracchi-Ricard V, Brambilla R, Levenson J, Hu WH, Bramwell A, Sweatt JD, Green EJ, Bethea JR. Astroglial nuclear factor-kappaB regulates learning and memory and synaptic plasticity in female mice. J Neurochem. 2008;104(3):611-23.

72. Teng FY, Tang BL. NF-kappaB signaling in neurite growth and neuronal survival. Rev Neurosci. 2010;21(4):299-313.

73. Widera D, Kaus A, Kaltschmidt C, Kaltschmidt B. Neural stem cells, inflammation and NF-kappaB: basic principle of maintenance and repair or origin of brain tumours? J Cell Mol Med. 2008;12(2):459-70.

74. Taupin P. Adult neurogenesis, neuroinflammation and therapeutic potential of adult neural stem cells. Int J Med Sci. 2008;5(3):127-32.

75. Widera D, Mikenberg I, Kaltschmidt B, Kaltschmidt C. Potential role of NFkappaB in adult neural stem cells: the underrated steersman? Int J Dev Neurosci. 2006:24(2-3):91-102.

76. Gutierrez H, Davies AM. Regulation of neural process growth, elaboration and structural plasticity by NF-kappaB. Trends Neurosci. 2011;34(6):316-25.

77. Zhang C, Wu H, Zhu X, Wang Y, Guo J. Role of transcription factors in neurogenesis after cerebral ischemia. Rev Neurosci. 2011;22(4):457-65.

78. Scholzke MN, Schwaninger M. Transcriptional regulation of neurogenesis: potential mechanisms in cerebral ischemia. J Mol Med (Berl). 2007;85(6):577-88.

79. Weinstein AM, Storkus WJ. Therapeutic lymphoid organogenesis in the tumor microenvironment. Adv Cancer Res. 2015;128:197-233.

80. Shen M, Zhou L, Zhou P, Zhou W, Lin X. Lymphotoxin beta receptor activation promotes mRNA expression of RelA and pro-inflammatory cytokines TNFalpha and IL-1 beta in bladder cancer cells. Mol Med Rep. 2017;16(1):937-42.

81. Fernandes MT, Ghezzo MN, Silveira AB, Kalathur RK, Povoa V, Ribeiro AR, Brandalise SR, Dejardin E, Alves NL, Ghysdael J, et al. Lymphotoxin-beta receptor in microenvironmental cells promotes the development of T-cell acute lymphoblastic leukaemia with cortical/mature immunophenotype. $\mathrm{Br}$ J Haematol. 2015;171(5):736-51.

82. Hu X, Zimmerman MA, Bardhan K, Yang D, Waller JL, Liles GB, Lee JR, Pollock R, Lev D, Ware CF, et al. Lymphotoxin beta receptor mediates caspasedependent tumor cell apoptosis in vitro and tumor suppression in vivo despite induction of NF-kappaB activation. Carcinogenesis. 2013;34(5):1105-14.

83. Wolf MJ, Seleznik GM, Heikenwalder M. Lymphotoxin's link to carcinogenesis: friend or foe? From lymphoid neogenesis to hepatocellular carcinoma and prostate cancer. Adv Exp Med Biol. 2011;691:231-49.

84. Wolf MJ, Seleznik GM, Zeller N, Heikenwalder M. The unexpected role of lymphotoxin beta receptor signaling in carcinogenesis: from lymphoid tissue formation to liver and prostate cancer development. Oncogene. 2010;29(36): 5006-18.

85. Mitsdoerffer M, Peters A. Tertiary lymphoid organs in central nervous system autoimmunity. Front Immunol. 2016;7:451.

86. Hoeijmakers L, Lucassen PJ, Korosi A. The interplay of early-life stress, nutrition, and immune activation programs adult hippocampal structure and function. Front Mol Neurosci. 2014;7:103.

87. Jeon SW, Kim YK. Neuroinflammation and cytokine abnormality in major depression: cause or consequence in that illness? World J Psychiatry. 2016; 6(3):283-93

88. Inoue M, Chen PH, Siecinski S, Li QJ, Liu C, Steinman L, Gregory SG, Benne E, Shinohara ML. An interferon-beta-resistant and NLRP3 inflammasomeindependent subtype of EAE with neuronal damage. Nat Neurosci. 2016; 19(12):1599-609.
89. Gommerman JL, Giza K, Perper S, Sizing I, Ngam-Ek A, Nickerson-Nutter C, Browning $\mathrm{J}$. A role for surface lymphotoxin in experimental autoimmune encephalomyelitis independent of LIGHT. J Clin Invest. 2003;112(5):755-67.

90. Plant SR, locca HA, Wang Y, Thrash JC, O'Connor BP, Arnett HA, Fu YX, Carson MJ, Ting JP. Lymphotoxin beta receptor (Lt betaR): dual roles in demyelination and remyelination and successful therapeutic intervention using Lt betaR-Ig protein. J Neurosci. 2007;27(28):7429-37.

91. Viatour P, Merville MP, Bours V, Chariot A. Phosphorylation of NF-kappaB and IkappaB proteins: implications in cancer and inflammation. Trends Biochem Sci. 2005;30(1):43-52.

92. Heo SK, Noh EK, Gwon GD, Kim JY, Jo JC, Choi Y, Koh S, Baek JH, Min YJ, Kim H. LIGHT (TNFSF14) increases the survival and proliferation of human bone marrow-derived mesenchymal stem cells. PLoS One. 2016;11(11):e0166589.

93. Kang JM, Yeon BK, Cho SJ, Suh YH. Stem cell therapy for alzheimer's disease: a review of recent clinical trials. J Alzheimers Dis. 2016:54(3):879-89.

94. Goldman SA. Stem and progenitor cell-based therapy of the central nervous system: hopes, hype, and wishful thinking. Cell Stem Cell. 2016;18(2):174-88.

95. Barnabe-Heider F, Goritz C, Sabelstrom H, Takebayashi H, Pfrieger FW, Meletis K, Frisen J. Origin of new glial cells in intact and injured adult spinal cord. Cell Stem Cell. 2010;7(4):470-82

96. Sabelstrom H, Stenudd M, Reu P, Dias DO, Elfineh M, Zdunek S, Damberg P, Goritz C, Frisen J. Resident neural stem cells restrict tissue damage and neuronal loss after spinal cord injury in mice. Science. 2013;342(6158):637-40

97. Liu Y, Tan B, Wang L, Long Z, Li Y, Liao W, Wu Y. Endogenous neural stem cells in central canal of adult rats acquired limited ability to differentiate into neurons following mild spinal cord injury. Int J Clin Exp Pathol. 2015; 8(4):3835-42.

98. Morrison SJ, Perez SE, Qiao Z, Verdi JM, Hicks C, Weinmaster G, Anderson DJ. Transient notch activation initiates an irreversible switch from neurogenesis to gliogenesis by neural crest stem cells. Cell. 2000;101(5):499-510.

99. Li J, Tang Y, Purkayastha S, Yan J, Cai D. Control of obesity and glucose intolerance via building neural stem cells in the hypothalamus. Mol Metab. 2014:3(3):313-24.

\section{Submit your next manuscript to BioMed Central and we will help you at every step:}

- We accept pre-submission inquiries

- Our selector tool helps you to find the most relevant journal

- We provide round the clock customer support

- Convenient online submission

- Thorough peer review

- Inclusion in PubMed and all major indexing services

- Maximum visibility for your research

Submit your manuscript at www.biomedcentral.com/submit 